\title{
Chromatographic characterization of juice in fruits of different Japanese quince (Chaenomeles japonica L.) genotypes cultivated in Sweden
}

\author{
María Pilar Hellín', María José Jordán', Kimmo Rumpunen², José María Ros García1* \\ ${ }^{1}$ Department of Food Science and Technology and Human Nutrition, University of Murcia, Campus de Espinardo, 30100 Murcia, Spain, \\ ${ }^{2}$ Department of Crop Science, Swedish University of Agricultural Sciences, Fjaelkestadsvaegen 459,29194 Kristianstad, Sweden
}

\section{A B S TR A C T}

The juice in fruits of 19 genotypes of Japanese quince (Chaenomeles japonica), representing plant breeding material, was characterised using high performance liquid chromatography. The juice was extracted by halving and squeezing the fruit. Samples of Japanese quince juice were always analysed fresh. The main compounds found were sugars: glucose (131-1056 mg $\left.100 \mathrm{ml}^{-1}\right)$, fructose (351-2515 mg $\left.100 \mathrm{ml}^{-1}\right)$ and sorbitol (10-367 mg $\left.100 \mathrm{ml}^{-1}\right)$; organic acids: malic acid (2.27-4.84 g $\left.100 \mathrm{ml}^{-1}\right)$ and quinic acid $\left(0.50-2.50 \mathrm{~g} 100 \mathrm{ml}^{-1}\right)$;

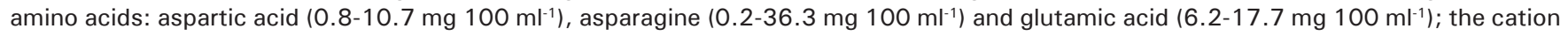
potassium (145-214 mg $\left.100 \mathrm{ml}^{-1}\right)$ and the anion fluoride (21-122 mg $\left.100 \mathrm{ml}^{-1}\right)$. These results on composition suggest that Japanese quince may be an interesting raw material source of valuable substances and its juice an ingredient for the food industry. A principal components analysis separated the Japanese quince genotypes, thus indicating a clear difference in the chemical composition of the juice.

Keywords: Chaenomeles japonica; Japanese quince; Fruits; Juice; Composition

\section{INTRODUCTION}

The family Chaenomeles belongs to Rosaceae. The genus Chaenomeles is originating from East Asia and has four species (Chaenomeles thibetica, Chaenomeles speciosa, Chaenomeles japonica and Chaenomeles cathayensis), which are considered as a potential crop in horticulture, due to the firmness of the fruits and the high content in juice (Hellín et al., 2003; Ros et al., 2004), and the fruit dietetic fibres (Thomas et al., 2000; Thomas and Thibault, 2002; Thomas et al., 2003). A horticultural program in North Europe, initially focussed in the Japanese quince (Chaenomeles japonica, Fig. 1, Fig. 2 and Fig. 3), was started in 1998 with the European Research Project entitled Japanese quince (Chaenomeles japonica) - A new european fruit crop for production of juice, flavour and fibre (FAIR5CT97-3894, 1998-2001). The purpose was to upgrade the plant by breeding and selection (Rumpunen et al., 1998; Rumpunen, 2002). For these purposes information on the (bio)chemical properties of the fruits is a clear requirement. The juice of Japanese quince can be an interesting ingredient of food, since it is very acidic and no cloudy (Hellín et al., 2003; Ros et al., 2004), being also of interest its antioxidant power, because the high amounts of compounds such as vitamin C and phenolics (Hellín et al., 2003; Ros et al., 2004). It is very important considering its use in industrial food production as an ingredient for acidification having antioxidative characteristics (Durec et al., 2019), making the Japanese quince a healthy fruit Watychowicz et al., 2017).

The scientific references on the properties and constituents of Chaenomeles and Chaenomeles juice is modest. There are some articles dealing on Chaenomeles composition and characteristics: sugars and acids (Lesinska, 1987), volatile and nonvolatile flavor components (Lesinska et al., 1988), complex carbohydrate (Golubev et al., 1990), pectic substances (Rumpunen, 1995; Thomas et al., 2003), Chaenomeles fruit juice (Hellín et al., 2003; Ros et al., 2004), fruit characteristics and processing potential (Tarko et al., 2014), tocochromanol composition in the seeds (Górnaś et al., 2014), natural

\footnotetext{
Corresponding author:

José María Ros García, Department of Food Science and Technology and Human Nutrition, University of Murcia, Campus de Espinardo, 30100 Murcia, Spain. E-mail: jmros@um.es
} 


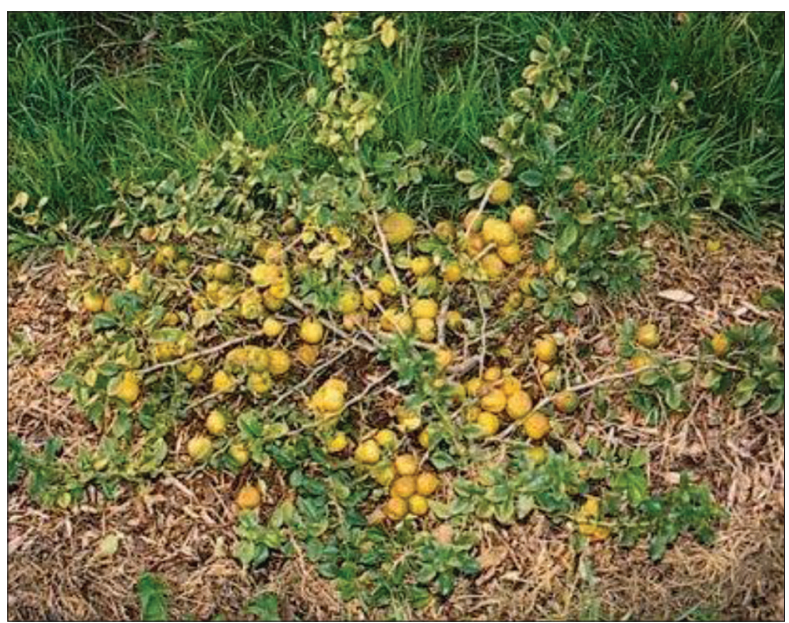

Fig 1. Chaenomeles japonica plant and fruits.

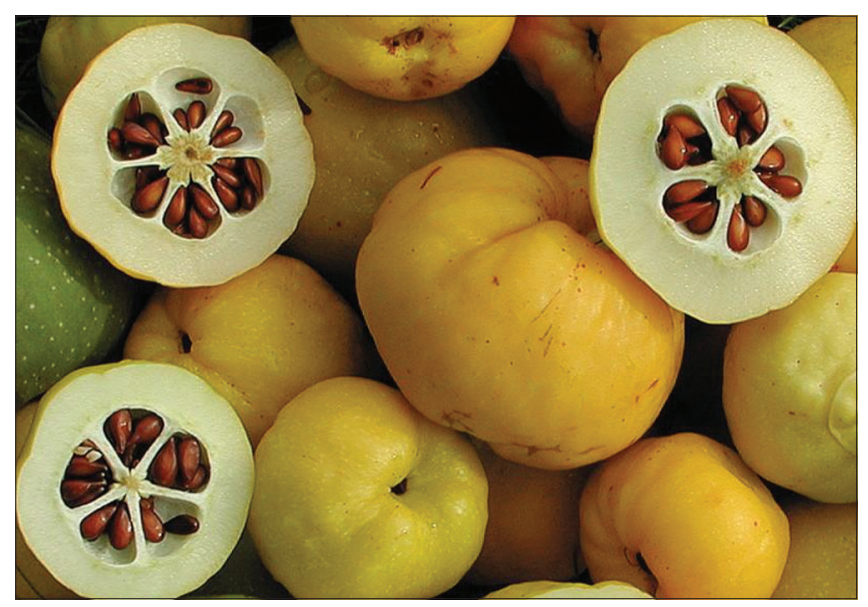

Fig 2. Chaenomeles japonica fruits.

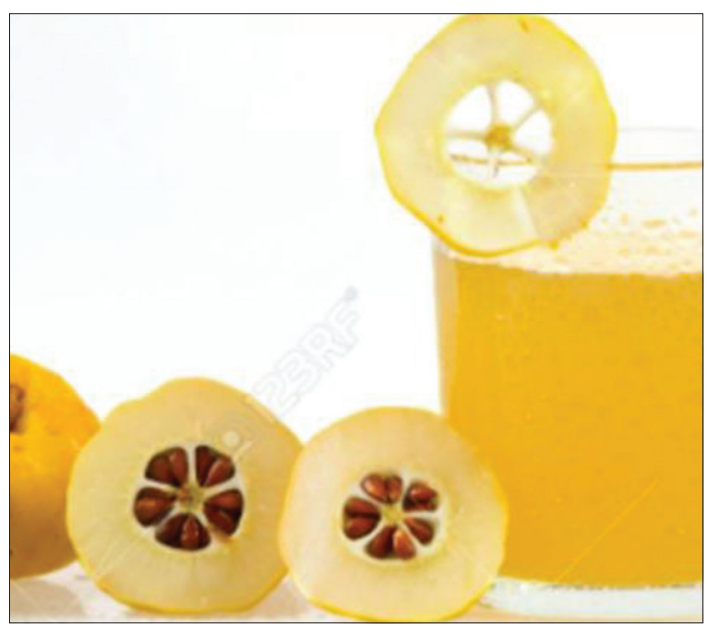

Fig 3. Chaenomeles japonica fruits and juice.

ingredient (Wojdyło et al., 2008), element content (Baranowska-Bosiacka et al., 2017; Komar-Tyomnaya and Dunaevskaya, 2017), active compounds (Miao et al., 2018), pentacyclic triterpenoids (Kikowska et al., 2018), antiamoebic and antimicrobial activities (Kikowska et al., 2019a), polyphenol-rich extracts (Kikowska et al., 2019b), industrial characteristics (Lykholat et al., 2019) and the review on Chaenomeles - health promoting benefits by Watychowicz et al. (2017).

Focusing on the previous works done on this topic (Lesinska et al., 1988; Rumpunen, 1995; Hellín et al., 2003; Ros et al., 2004; Baranowska-Bosiacka et al., 2017), the objective of this study was to characterise Japanese quince juice using high performance liquid chromatography analyses of sugars, organic acids, amino acids and ions in fruits of different genotypes cultivated in Sweden. An analysis of the principal components (PCA) of the results was also made to show global differences between genotypes on the basis of the results of juice characterization.

\section{MATERIALS AND METHODS}

\section{Plant material and fruits}

The origin and denomination of the Chaenomeles japonica plants (Fig. 1) from which fruits (Fig. 2 and Fig. 3) were sampled for chromatographic characterisation of its juice (Fig. 3) are given in Table 1. In total, 19 genotypes of Japanese quince (Chaenomeles japonica), representing plant breeding material, were extracted and characterised. The plants sampled were cultivated in different test plots (D, NV and RG) at the Department of Crop Science, Swedish University of Agricultural Sciences, Kristianstad, Sweden (56 $\left.07^{\circ} \mathrm{N}, 14^{\circ} 10^{\prime} \mathrm{E}\right)$. The soil differed between the test plots, in that the NV soil was sandier compared to D and RG soils, which contained considerably more clay. The different populations, from which the plants were sampled, were collected and established during a period of four years. Thus, the plants sampled were of different age. However, all fruits of Japanese quince were sampled at the same developmental stage, when the fruit skin had turned yellow and the seeds had turned brown, indicating maturity (Ros et al., 2004). Following harvesting (September 2000) the fruits were sent to Spain for chromatographic analysis, which was performed immediately once the fruits were received.

\section{Fruit fractionation}

Fruits (1 kg of each genotype, 10-12 units) were fractionated into pulp, juice and seeds (Ros et al., 2004). The juice was extracted by halving and squeezing the fruit. For this purpose, a Frutelia AV5 juice extractor from Moulinex (France) was used. Samples of Japanese quince juice were always analysed fresh. To avoid modification of the composition and characteristics of the fresh juice, no thermal treatment was carried-out. Juice samples were 
Table 1: Origin and denomination of the Japanese quince (Chaenomeles japonica) plants from which fruits were sampled for chromatographic characterization of its juice

\begin{tabular}{|c|c|c|c|c|}
\hline Genotypes $^{\mathrm{a}}$ & Specie & Population & Seed source ${ }^{b}$ & Origin \\
\hline D 3-122 & C. japonica & 9226 & orchard, open pollination & Lithuania \\
\hline D 5-96 & C. japonica & 9236 & orchard, open pollination & Lithuania \\
\hline D $10-19$ & C. japonica & 9218 & orchard, open pollination & Lithuania \\
\hline NV 14-73 & C. japonica & 9401 & orchard, crossing (9368x9363) & Lithuania \\
\hline NV 15-97 & C. japonica & 9403 & orchard, crossing $(9363 \times 9368)$ & Lithuania \\
\hline NV $17-18$ & C. japonica & 9411 & orchard, crossing (9366x9368) & Lithuania \\
\hline NV 18-34 & C. japonica & 9403 & orchard, crossing $(9363 \times 9368)$ & Lithuania \\
\hline NV 19-27 & C. japonica & 9401 & orchard, crossing (9368x9363) & Lithuania \\
\hline NV 19-44 & C. japonica & 9411 & orchard, crossing (9366x9368) & Lithuania \\
\hline NV 19-64 & C. japonica & 9403 & orchard, crossing $(9363 \times 9368)$ & Lithuania \\
\hline NV 19-108 & C. japonica & 9401 & orchard, crossing (9368x9363) & Lithuania \\
\hline RG 1-27 & C. japonica & 9161 & orchard, open pollination & Lithuania \\
\hline RG 6-104 & C. japonica & 9138 & orchard, open pollination & Latvia \\
\hline RG 6-111 & C. japonica & 9138 & orchard, open pollination & Latvia \\
\hline RG 6-132 & C. japonica & 9138 & orchard, open pollination & Latvia \\
\hline RG 7-50 & C. japonica & 9136 & orchard, open pollination & Latvia \\
\hline RG 7-69 & C. japonica & 9135 & orchard, open pollination & Latvia \\
\hline RG 8-22 & C. japonica & 9134 & orchard, open pollination & Latvia \\
\hline RG 8-25 & C. japonica & 9134 & orchard, open pollination & Latvia \\
\hline
\end{tabular}

aLetters D, NV and RG represent different test plots at the Department of Crop Science, Swedish University of Agricultural Sciences, where the plants were

cultivated $\left(56^{\circ} 07^{\prime} \mathrm{N}, 14^{\circ} 10^{\prime} \mathrm{E}\right)$. ' In the crossing combinations the numbers 9363,9366 and 9368 represent three different seed- and pollen-parents of $C$. japonica

frozen $\left(-20^{\circ} \mathrm{C}\right)$ until the chromatographic analyses were made.

\section{Sample treatment before high performance liquid chromatography analysis}

Once the juice samples have been thawed and stirred for homogenization, the samples of juice were centrifuged previously to direct injection for high performance liquid chromatography (HPLC) analysis (González-Hidalgo et al., 2019).

\section{High performance liquid chromatography analysis of the Japanese quince juice}

Sugars and organic acids were analysed by HPLC according to Hellín et al. (2001). Amino acids and inorganic ions were analysed by HPLC according to Hellín et al. (2003).

\section{Statistical analyses}

The samples were analysed in triplicate and an average value was calculated for the juice from a representative sample $(1 \mathrm{~kg})$ of each genotype. For each analysed parameter in triplicate an average value, its corresponding standard deviation $\left(s_{x}\right)$ and an analysis of the variance (ANOVA) was also calculated based on the 19 genotypes sampled. Scheffé's homogeneity means test $(p<0.05)$ was used. The statistical computer program used was Statistix 8 for Windows. Pearson's correlation coefficients and a principal component analysis (PCA) of the composition of Japanese quince genotypes fresh juice were obtained using SPSS 10.0 for Windows (SPSS Inc., Chicago, IL).

\section{RESULTS AND DISCUSSION}

\section{Sugars content in Japanese quince genotypes fresh juice}

The concentration of sugars found in Japanese quince genotypes fresh juice is shown in Table 2. Nine sugars were found: the tetrasaccharide stachyose, the trisaccharide raffinose, the disaccharide sucrose, and the monosaccharides glucose, xylose, rhamnose, fructose, inositol and sorbitol. The sugars content of Japanese quince juice was different between the genotypes. Main sugars were fructose (351-

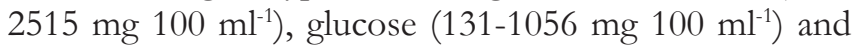
sorbitol (10-367 mg $100 \mathrm{ml}^{-1}$ ). The differences between the results of sugars content are statistically significatives $(\mathrm{p}<0.05)$ (Table 2).

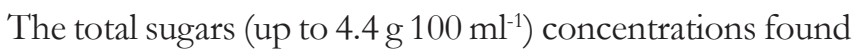
for the different Japanese quince genotypes juices are in agreement with the soluble solids (up to $8.8^{\circ} \mathrm{Brix}$ ) reported in the same Japanese quince genotypes juices by Ros et al. (2004). It should be considered that the refractometric measure of the soluble solids is a contribution of both soluble sugars and organic acids, which are also in high concentration in these juices (see below). Fructose, glucose and sorbitol are the same major sugars reported by Lesinska (1987) also in Japanese quince. Our results also agree in the range of concentrations in which those sugars are presents in Japanese quince juice, although some differences have been found respect to the results of Lesinska (1987), mainly due to the fact that we determine free sugars soluble in the juice and Lesinska (1987) determine all sugars 


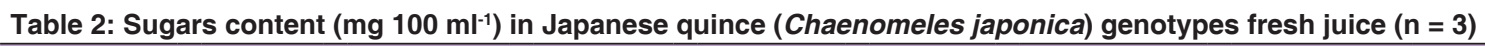

\begin{tabular}{|c|c|c|c|c|c|c|c|c|c|}
\hline Genotypes & Stach ${ }^{1}$ & Raffinose & Sucrose & Glucose & Xylose & Rhamnose & Fructose & Inositol & Sorbitol \\
\hline D 3-122 & nd & $39^{a}$ & $55^{b}$ & $1056^{a}$ & $285^{a}$ & $110^{a}$ & $2515^{a}$ & nd & $311^{\mathrm{b}}$ \\
\hline D 5-96 & $1^{g}$ & $2^{g}$ & $2^{\mathrm{h}}$ & $457^{f}$ & $86^{e}$ & $19^{c}$ & $939^{f}$ & $20^{a}$ & $249^{c}$ \\
\hline D $10-19$ & $2^{f}$ & $21^{b}$ & $59^{b}$ & $405^{f}$ & $78^{e}$ & $24^{c}$ & $888^{9}$ & $7^{d}$ & $187^{e}$ \\
\hline NV 14-73 & $9^{c}$ & $1^{\mathrm{h}}$ & $33^{c}$ & $335^{9}$ & $71^{\mathrm{e}}$ & $16^{d}$ & $841^{g}$ & $10^{d}$ & $173^{e}$ \\
\hline NV 15-97 & $2^{f}$ & $5^{e}$ & $54^{\mathrm{b}}$ & $137^{\mathrm{h}}$ & $159^{b}$ & $9^{f}$ & $514^{\mathrm{h}}$ & $5^{e}$ & $90^{9}$ \\
\hline NV $17-18$ & $2^{f}$ & $3^{f}$ & $31^{c}$ & $131^{\mathrm{h}}$ & $99^{d}$ & $7^{f}$ & $351^{\mathrm{j}}$ & nd & $87^{9}$ \\
\hline NV 18-34 & nd & $9^{d}$ & $21^{d}$ & $553^{e}$ & $115^{c}$ & nd & $1339^{d}$ & nd & $179^{e}$ \\
\hline NV 19-27 & $13^{b}$ & $17^{c}$ & $19^{d}$ & $299^{9}$ & $71^{\mathrm{e}}$ & $13^{e}$ & $951^{\dagger}$ & $16^{b}$ & $10^{\mathrm{h}}$ \\
\hline NV 19-44 & $6^{d}$ & $1^{\mathrm{h}}$ & $8^{f}$ & $399^{f}$ & $75^{e}$ & $16^{d}$ & $972^{f}$ & $9^{d}$ & $118^{f}$ \\
\hline NV 19-64 & $4^{e}$ & $11^{\mathrm{d}}$ & $303^{a}$ & $448^{f}$ & $55^{\dagger}$ & $4^{g}$ & $1056^{e}$ & $3^{f}$ & $136^{4}$ \\
\hline NV 19-108 & $22^{a}$ & $20^{b}$ & $12^{\mathrm{e}}$ & $137^{\mathrm{h}}$ & $131^{c}$ & $18^{c}$ & $490^{h}$ & $5^{e}$ & $124^{\dagger}$ \\
\hline RG 1-27 & $2^{f}$ & $3^{f}$ & nd & $660^{d}$ & $51^{\dagger}$ & nd & $1338^{d}$ & $7^{d}$ & $367^{a}$ \\
\hline RG 6-104 & $2^{f}$ & $4^{f}$ & $13^{e}$ & $619^{d}$ & $169^{b}$ & $32^{b}$ & $1621^{b}$ & $14^{b}$ & $353^{a}$ \\
\hline RG 6-111 & $4^{e}$ & nd & $4^{g}$ & $698^{\circ}$ & $55^{\dagger}$ & nd & $1326^{d}$ & nd & $303^{b}$ \\
\hline RG 6-132 & $2^{f}$ & $6^{e}$ & $1^{i}$ & $682^{c}$ & $20^{g}$ & nd & $1010^{e}$ & nd & $237^{\circ}$ \\
\hline RG 7-50 & nd & nd & nd & $732^{\circ}$ & $53^{f}$ & nd & $1386^{d}$ & $15^{b}$ & $305^{b}$ \\
\hline RG 7-69 & nd & $3^{f}$ & $23^{d}$ & $432^{\mathrm{e}}$ & $29^{9}$ & nd & $1013^{e}$ & $12^{c}$ & $116^{t}$ \\
\hline RG 8-22 & nd & nd & $10^{f}$ & $470^{e}$ & $81^{e}$ & $13^{e}$ & $397^{i}$ & $12^{\mathrm{c}}$ & $217^{d}$ \\
\hline RG 8-25 & nd & nd & nd & $923^{b}$ & $25^{g}$ & nd & $1490^{\circ}$ & $9^{d}$ & $228^{d}$ \\
\hline Range & $1-22$ & $1-39$ & $1-303$ & $131-1056$ & $20-285$ & $4-110$ & $351-2515$ & $3-20$ & $10-367$ \\
\hline Mean & 6 & 10 & 40 & 504 & 90 & 23 & 1076 & 10 & 200 \\
\hline$s_{x}$ & 6 & 11 & 73 & 253 & 63 & 28 & 507 & 5 & 99 \\
\hline
\end{tabular}

${ }^{1}$ Stachyose. nd: no detected. Means in column with different letters $(a-j)$ are significantly different $(p<0.05)$

from the fruit, which includes the sugars components of the polysaccharides included in the structure of the Japanese quince cell wall. The high performance size exclusion chromatography analysis shown the absence of polysaccharides and oligosaccharides in the juice (Ros et al., 2004). No hydrolytic enzymes of polysaccharides are expected to find in the juice (Apolinar-Valiente et al., 2017). The composition of those polysaccharides (from the fruit pulp) was established by Golubev et al. (1990) and Thomas et al. $(2000,2003)$ and Thomas and Thibault (2002). Valcheva-Kuzmanova et al. (2018) also reported in juice of Chaenomeles maulei the absence of soluble polysaccharides, and, as main sugars, glucose $\left(1.7 \mathrm{~g} 100 \mathrm{ml}^{-}\right.$

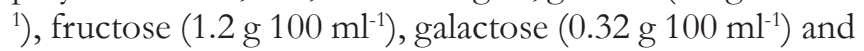
sucrose $\left(0.19 \mathrm{mg} 100 \mathrm{ml}^{-1}\right)$, which is similar, but not the same, to Chaenomeles japonica.

It is interesting to compare the Japanese quince sugars profile in the juice with that from different fruits. The fructose content in juice from other fruits is: apple cv. Red

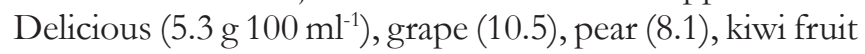

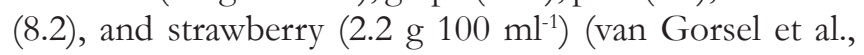
1992). Viljakainen et al. (2002) found a fructose amount

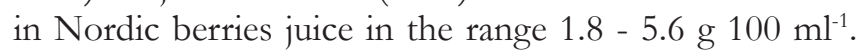
Hellín et al. (2003) reported the following fructose content

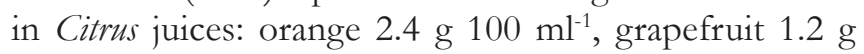

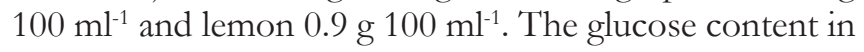

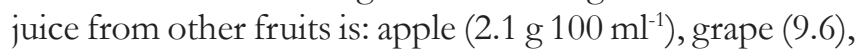
pear (1.7), kiwi fruit (6.9), and strawberry (1.8 g $\left.100 \mathrm{ml}^{-1}\right)$ (van Gorsel et al., 1992). Viljakainen et al. (2002) found a glucose amount in Nordic berries juice in the range 2.2 $5.0 \mathrm{~g} 100 \mathrm{ml}^{-1}$. Hellín et al. (2003) reported the following

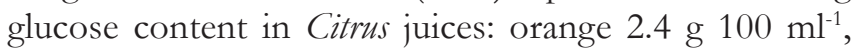

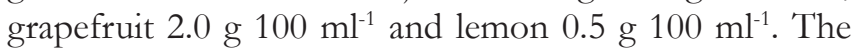
sorbitol content in juice from other fruits is: apple (0.2) and pear (4.1 g $\left.100 \mathrm{ml}^{-1}\right)$ (van Gorsel et al., 1992). Japanese quince juice can be a source of sorbitol, which is found broadly as a constituent of the vegetables, but in general in smaller amounts. The sweetness power of the sorbitol is half of the sucrose and it is also used as a humectant. The sucrose content in juice from other fruits is: apple $(0.8)$, grape (0.3), pear (0.6), kiwi fruit (1.8), and strawberry (0.2 g $100 \mathrm{ml}^{-1}$ ) (van Gorsel et al., 1992). Viljakainen et al. (2002) found a sucrose amount in Nordic berries juice in the range

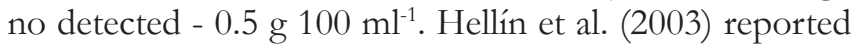
the following glucose content in Citrus juices: sucrose $4.7 \mathrm{~g}$

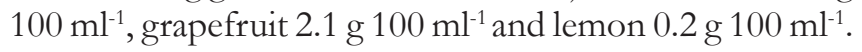

\section{Organic acids content in Japanese quince genotypes fresh juice}

The concentration of organic acids found in Japanese quince genotypes fresh juice is shown in Table 3. The chromatographic analysis of organic acids indicated that the Japanese quince genotypes fresh juice is constituted by

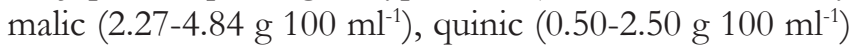
and succinic acid (4-12 mg $\left.100 \mathrm{ml}^{-1}\right)$. The organic acids content of Japanese quince juice was different between the genotypes. The differences between the results of organic acids content are statistically significatives $(p<0.05)$ (Table 3). 
Table 3: Organic acids content (mg $\left.100 \mathrm{ml}^{-1}\right)$ in Japanese quince (Chaenomeles)

\begin{tabular}{lccc}
\hline $\begin{array}{l}\text { japonica) genotypes } \\
\text { fresh juice }(\mathbf{n}=3)\end{array}$ & Malic acid & Quinic acid & Succinic acid \\
\hline D 3-122 & $4.84^{\mathrm{a}}$ & $1.48^{\mathrm{b}}$ & $0.004^{\mathrm{e}}$ \\
D 5-96 & $3.10^{\mathrm{e}}$ & $0.90^{\mathrm{c}}$ & $0.008^{\mathrm{c}}$ \\
D 10-19 & $3.97^{\mathrm{c}}$ & $1.29^{\mathrm{b}}$ & $0.006^{\mathrm{d}}$ \\
NV 14-73 & $3.21^{\mathrm{e}}$ & $1.23^{\mathrm{b}}$ & $0.009^{\mathrm{b}}$ \\
NV 15-97 & $2.92^{\mathrm{e}}$ & $1.31^{\mathrm{b}}$ & nd \\
NV 17-18 & $3.26^{\mathrm{e}}$ & $0.86^{\mathrm{c}}$ & $0.005^{\mathrm{d}}$ \\
NV 18-34 & $3.65^{\mathrm{d}}$ & $0.99^{\mathrm{c}}$ & nd \\
NV 19-27 & $3.08^{\mathrm{e}}$ & $1.18^{\mathrm{b}}$ & $0.006^{\mathrm{d}}$ \\
NV 19-44 & $3.44^{\mathrm{d}}$ & $0.98^{\mathrm{c}}$ & $0.012^{\mathrm{a}}$ \\
NV 19-64 & $3.65^{\mathrm{d}}$ & $0.99^{\mathrm{c}}$ & $\mathrm{nd}$ \\
NV 19-108 & $2.27^{\mathrm{g}}$ & $1.44^{\mathrm{b}}$ & $0.010^{\mathrm{b}}$ \\
RG 1-27 & $3.00^{\mathrm{e}}$ & $0.60^{\mathrm{d}}$ & $0.005^{\mathrm{d}}$ \\
RG 6-104 & $4.38^{\mathrm{b}}$ & $0.97^{\mathrm{c}}$ & $0.008^{\mathrm{c}}$ \\
RG 6-111 & $3.00^{\mathrm{e}}$ & $0.60^{\mathrm{d}}$ & $0.008^{\mathrm{c}}$ \\
RG 6-132 & $3.10^{\mathrm{e}}$ & $2.50^{\mathrm{a}}$ & $0.009^{\mathrm{b}}$ \\
RG 7-50 & $2.70^{\mathrm{f}}$ & $0.50^{\mathrm{d}}$ & $0.012^{\mathrm{a}}$ \\
RG 7-69 & $3.00^{\mathrm{e}}$ & $0.90^{\mathrm{c}}$ & $0.012^{\mathrm{a}}$ \\
RG 8-22 & $4.13^{\mathrm{c}}$ & $0.84^{\mathrm{c}}$ & $0.009^{\mathrm{b}}$ \\
RG 8-25 & $3.90^{\mathrm{c}}$ & $0.50^{\mathrm{d}}$ & $0.005^{\mathrm{d}}$ \\
Range & $2.27-4.84$ & $0.50-2.50$ & $0.004-0.012$ \\
Mean & 3.40 & 1.06 & 0.008 \\
S & 0.63 & 0.46 & 0.003 \\
\hline nd: no detected. Means in column with different letters (a-g) are significantly \\
different (p<0.05) & & &
\end{tabular}

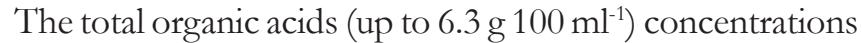
found for the different Japanese quince genotypes juices are in agreement with the titratable acidity (up to $5.6 \%$ anhydrous citric acid) reported in the same Japanese quince genotypes juices by Ros et al. (2004). Malic acid and quinic acid are the same major organic acids reported by Lesinska (1987) and Rumpunen (1995). Our results also agree in the range of concentrations in which those acids are presents in Japanese quince juice. Valcheva-Kuzmanova et al. (2018) reported in juice of Chaenomeles maulei a malic acid content

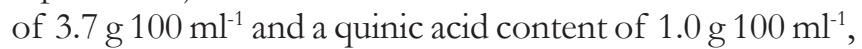
which is the same content of the genotype NV 18-34. They also found citric acid $\left(51 \mathrm{mg} 100 \mathrm{ml}^{-1}\right)$, absent in Chaenomeles japonica juice. Baranowska-Bosiacka et al. (2017) reported the presence of oxalate $(8.2 \mathrm{mg} / 100 \mathrm{~g})$, which is of the same order of magnitude that succinic acid (Table 3).

For comparison, the content of malic acid in other fruit juices is: apple cv. Red Delicious (0.5), grape (0.3), kiwi fruit (0.5), pear (0.4), and strawberry (0.2 g $100 \mathrm{ml}^{-1}$ ) (van Gorsel et al., 1992). In juice from Nordic berries it is reported

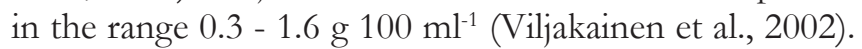
Concerning quinic acid, van Gorsel et al. (1992) reported

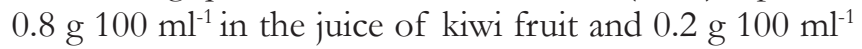
in the juice of pear. Heimler and Pieroni (1992) found in apple cv. Summerred low amounts $\left(0.2 \mathrm{mg} 100 \mathrm{ml}^{-1}\right)$ of succinic acid and fumaric acid. The organic acids profile of apple cv. Glockenapfel juice is also similar (Ackermann et al., 1992).

The very high malic acid content of Japanese quince juice makes it undrinkable. In order to obtain a Japanese quince juice with lower acidity, it is possible to carry-out its fermentation with malolactic bacteria, since the acidity of Nordic berries was reduced by fermentation with Oenococcus oeni (Viljakainen and Laakso, 2002).

The industry uses malic and succinic acid as agents of acidification. In fact, in the list of allowed additives, malic acid has the E-296 number and succinic acid the E-363. Quinic acid is not included in the list of allowed additives. Quinic acid uses mainly concern organic chemistry, since this acid contain three atoms of carbon with chirality properties and can be used as a building molecule that provide these chirality (Barco et al., 1997; Huang, 1999).

Considering that the content of acids in the juice of Japanese quince is high, it can be used in the same way that lemon juice (Saura et al., 1990) as a natural ingredient for acidification of foods with antioxidative characteristics (Hellín et al., 2003; Ros et al., 2004).

\section{Amino acids content in Japanese quince genotypes fresh juice}

The Table 4 provides the concentration of amino acids in the fresh juice of Japanese quince genotypes. As Table 4 shows, the content in amino acids was different between the genotypes. Main amino acids were phosphoserine (1.9-7.9 mg $\left.100 \mathrm{ml}^{-1}\right)$, aspartic acid $\left(0.8-10.7 \mathrm{mg} 100 \mathrm{ml}^{-1}\right)$, asparagine $\left(0.2-36.3 \mathrm{mg} 100 \mathrm{ml}^{-1}\right)$ and glutamic acid (6.2-17.7 $\left.\mathrm{mg} 100 \mathrm{ml}^{-1}\right)$. In most of the genotypes, the concentration of the other amino acids (alanine, phenylalanine, $\gamma$-aminobutiric acid (GABA) and lysine) was lower than $2 \mathrm{mg} 100 \mathrm{ml}^{-1}$. The differences between the results of amino acids content are statistically significatives $(\mathrm{p}<0.05)($ Table 4).

Considering the importance of amino acids found in the juice of Japanese quince for human nutrition, threonine, phenylalanine and lysine are essential amino acids. It means that the intake is only from the diet. The $\gamma$-aminobutiric acid is a neurotransmitter of the brain. Being amino acids compounds of interest, quantitatively are lower (up to

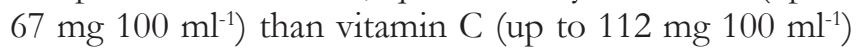
and phenols (up to $413 \mathrm{mg} 100 \mathrm{ml}^{-1}$ ), as was reported in the same genotypes juice by Ros et al. (2004).

It is very interesting to compare the amino acids composition of Japanese quince juices with that from other fruits. Following the analytical results of van Gorsel et al. (1992), expressed as mg of amino acid $100 \mathrm{ml}^{-1}$ of 
Hellín, et al.

Table 4: Amino acids content ( $\left(\mathrm{mg} 100 \mathrm{ml}^{-1}\right)$ in Japanese quince (Chaenomeles japonica) genotypes fresh juice $(\mathrm{n}=3)$

\begin{tabular}{|c|c|c|c|c|c|c|c|c|c|c|}
\hline Genotypes & Phosphoserine & $\begin{array}{l}\text { Aspartic } \\
\text { acid }\end{array}$ & Threonine & Serine & Asparagine & $\begin{array}{c}\text { Glutamic } \\
\text { acid }\end{array}$ & Alanine & Phenylalanine & GABA $^{a}$ & Lysine \\
\hline D 3-122 & $5.0^{d}$ & $5.4^{c}$ & $0.6^{\mathrm{b}}$ & $2.1^{d}$ & $0.9^{j}$ & $9.3^{f}$ & $0.4^{\mathrm{d}}$ & nd & nd & $0.5^{c}$ \\
\hline D 5-96 & $2.0^{\mathrm{h}}$ & $2.4^{e}$ & nd & $0.7^{g}$ & nd & $6.2^{\mathrm{h}}$ & $0.3^{e}$ & nd & nd & nd \\
\hline D $10-19$ & $2.8^{f}$ & $3.8^{d}$ & $0.5^{c}$ & $1.1^{t}$ & $1.0^{\mathrm{j}}$ & $10.8^{e}$ & $0.5^{d}$ & nd & $0.3 b$ & $0.1^{\mathrm{d}}$ \\
\hline NV $14-73$ & $3.6^{e}$ & $4.2^{\mathrm{d}}$ & $0.4^{d}$ & $1.0^{\mathrm{f}}$ & $4.7^{\dagger}$ & $8.3^{f}$ & $0.6^{d}$ & $0.3^{d}$ & $0.3 b$ & nd \\
\hline NV 15-97 & $5.7^{c}$ & $2.9^{e}$ & $0.6^{b}$ & $1.7^{\mathrm{e}}$ & $1.3^{\mathrm{j}}$ & $10.9^{e}$ & $0.9^{c}$ & $1.3^{b}$ & $0.7 a b$ & $0.8^{\mathrm{b}}$ \\
\hline NV $17-18$ & $7.9^{a}$ & $0.9^{9}$ & $0.2^{\mathrm{e}}$ & $1.4^{f}$ & $0.4^{\mathrm{k}}$ & $17.3^{a}$ & $1.3^{b}$ & 1.0 & $0.9 a$ & $0.5^{c}$ \\
\hline NV 18-34 & $5.4^{c}$ & $0.8^{9}$ & $0.5^{c}$ & $2.1^{d}$ & $2.8^{\mathrm{h}}$ & $14.6^{b}$ & $2.6^{a}$ & $4.4^{\mathrm{a}}$ & $1.0 \mathrm{a}$ & $0.3^{\mathrm{d}}$ \\
\hline NV 19-27 & $6.8^{\mathrm{b}}$ & $3.0^{\mathrm{e}}$ & $0.5^{c}$ & $1.8^{\mathrm{e}}$ & $1.0^{\mathrm{j}}$ & $11.3^{\mathrm{e}}$ & $1.5^{\mathrm{b}}$ & $1.2^{\mathrm{b}}$ & $0.8 \mathrm{a}$ & $0.8^{\mathrm{b}}$ \\
\hline NV 19-44 & $5.9^{c}$ & $1.4^{f}$ & $0.5^{c}$ & $4.0^{\mathrm{b}}$ & $2.1^{i}$ & $17.7^{a}$ & $1.3^{b}$ & $1.0^{\mathrm{b}}$ & $0.8 a$ & $0.4^{\text {cd }}$ \\
\hline NV 19-64 & $4.8^{d}$ & $4.7^{c}$ & $0.4^{d}$ & $1.1^{t}$ & $3.5^{\mathrm{g}}$ & $8.7^{f}$ & $0.5^{\mathrm{d}}$ & nd & $0.8 a$ & $0.3^{\mathrm{d}}$ \\
\hline NV 19-108 & $5.7^{c}$ & $4.7^{c}$ & $0.6^{b}$ & $2.2^{\mathrm{d}}$ & $1.1^{\mathrm{h}}$ & $11.0^{\mathrm{e}}$ & $0.7^{d}$ & $1.0^{\mathrm{b}}$ & $0.9 a$ & $0.5^{c}$ \\
\hline RG 1-27 & $2.2^{\mathrm{g}}$ & $9.9^{\mathrm{a}}$ & $1.2^{\mathrm{a}}$ & $4.2^{\mathrm{b}}$ & $36.3^{a}$ & $12.2^{\mathrm{d}}$ & $0.7^{d}$ & nd & nd & nd \\
\hline RG 6-104 & $3.8^{e}$ & $5.1^{c}$ & $0.7^{b}$ & $2.9^{c}$ & $6.6^{e}$ & $9.9^{f}$ & $0.6^{d}$ & nd & $0.5 b$ & $1.3^{\mathrm{a}}$ \\
\hline RG 6-111 & $2.4^{\mathrm{g}}$ & $4.9^{c}$ & $0.2^{\mathrm{e}}$ & $0.2^{\mathrm{h}}$ & $2.0^{\circ}$ & $6.3^{\mathrm{h}}$ & $0.4^{\mathrm{e}}$ & nd & nd & $0.7^{\mathrm{b}}$ \\
\hline RG 6-132 & $2.6^{f}$ & $7.5^{\mathrm{b}}$ & $1.2^{\mathrm{a}}$ & $4.9^{\mathrm{a}}$ & $8.7^{d}$ & $11.1^{\mathrm{e}}$ & $0.7^{d}$ & nd & nd & nd \\
\hline RG 7-50 & $1.9^{\mathrm{h}}$ & $10.7^{a}$ & $1.1^{\mathrm{a}}$ & $3.8^{\mathrm{b}}$ & $15.9^{b}$ & $11.0^{\mathrm{e}}$ & $1.0^{c}$ & $0.1^{d}$ & $0.4 b$ & $0.1^{d}$ \\
\hline RG 7-69 & $2.2^{\mathrm{g}}$ & $5.0^{c}$ & $0.3^{e}$ & $0.9^{f}$ & $0.2^{k}$ & $7.7^{\mathrm{g}}$ & $0.3^{e}$ & nd & nd & $0.7^{\mathrm{b}}$ \\
\hline RG 8-22 & $3.6^{e}$ & $5.7^{c}$ & $0.8^{b}$ & $1.9^{e}$ & $4.5^{\mathrm{e}}$ & $13.2^{\mathrm{c}}$ & $0.7^{d}$ & nd & nd & nd \\
\hline RG 8-25 & $2.2^{\mathrm{g}}$ & $4.2^{d}$ & $0.6^{\mathrm{b}}$ & $1.8^{\mathrm{e}}$ & $10.9^{c}$ & $11.1^{\mathrm{e}}$ & $0.5^{\mathrm{d}}$ & $0.6^{c}$ & $0.3 b$ & nd \\
\hline Range & $1.9-7.9$ & $0.8-10.7$ & $0.2-1.2$ & $0.2-4.9$ & $0.2-36.3$ & $6.2-17.7$ & $0.3-2.6$ & $0.1-4.4$ & $0.3-1.0$ & $0.1-1.3$ \\
\hline Mean & 4.0 & 4.6 & 0.6 & 2.1 & 5.5 & 11.0 & 0.8 & 0.6 & 0.4 & 0.4 \\
\hline$s_{x}$ & 1.8 & 2.6 & 0.3 & 1.3 & 8.6 & 3.1 & 0.6 & 1.0 & 0.4 & 0.4 \\
\hline
\end{tabular}

${ }^{a}$ GABA: gammaaminobutiric acid. nd: no detected. Means in column with different letters $(a-k)$ are significantly different $(p<0.05)$

fruit juice, aspartic acid appears in many fruit juices and in considerable quantities: apple cv. Red Delicious (16), grape (8), kiwi fruit (10), pear (13) and strawberry (11). Grape juice mainly contains proline (101), arginine (59), and alanine (17). Kiwi fruit contains a broad profile of amino acids (threonine, serine, proline, alanine, valine, isoleucine, leucine, tyrosine, phenylalanine, tryptophan, cysteine, lysine, histidine, and arginine), all of them at a maximum of $5 \mathrm{mg} 100 \mathrm{ml}^{-1}$. Strawberry juice mainly contains alanine (14) and serine (10). Apple juice (Ackermann et al., 1992) mainly contains asparagine (89), aspartic acid (11), and $\gamma$-aminobutiric acid, alanine and serine $\left(1 \mathrm{mg} 100 \mathrm{ml}^{-1}\right)$. Hellín et al. (2003) reported that Citrus juices contain a high amount of aspartic acid (up to $470 \mathrm{mg} 100 \mathrm{ml}^{-1}$

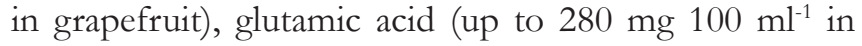

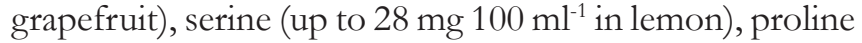

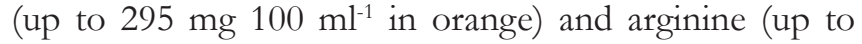
$150 \mathrm{mg} 100 \mathrm{ml}^{-1}$ in lemon and orange). In general, no glutamic acid has been reported in the juice of those fruits (except Citrus), while in Japanese quince was the major, in agreement with Lesinska (1987).

\section{lons content in Japanese quince genotypes fresh juice}

The concentration of inorganic cations and anions found in Japanese quince genotypes fresh juice is shown in Table 5. Five cationic and two anionic components were found: sodium, ammonium, potassium, magnesium and calcium; fluoride and chloride. The cations and anions content of Japanese quince juice was different between the genotypes. Main cations were potassium $(145-214 \mathrm{mg}$ $\left.100 \mathrm{ml}^{-1}\right)$, calcium (8.0-15.1 mg $\left.100 \mathrm{ml}^{-1}\right)$ and magnesium (3.9-8.7 mg/100 $\left.\mathrm{ml}^{-1}\right)$. Main anions were fluoride (21$122 \mathrm{mg} 100 \mathrm{ml}^{-1}$ ) and chloride (1.4-9.4 mg $100 \mathrm{ml}^{-1}$ ). The differences between the results of ions content are statistically significatives $(p<0.05)$ (Table 5).

The low found sodium content (up to $12 \mathrm{mg} 100 \mathrm{ml}^{-1}$ ) is interesting in human nutrition, since sodium is responsible for blood pressure. Baranowska-Bosiacka et al. (2017) reported the presence of potassium $(249.7 \mathrm{mg} / 100 \mathrm{~g}$ dry weight), phosphorus (64.1 mg/100 g dry weight), calcium (22.9 mg/100 g dry weight), magnesium (16.7 mg/100 g dry weight), and sodium ( $2.8 \mathrm{mg} / 100 \mathrm{~g}$ dry weight), in Chaenomeles japonica. These data are lower than what we found in Chaenomeles japonica. Komar-Tyomnaya and Dunaevskaya (2017) reported average values of potassium

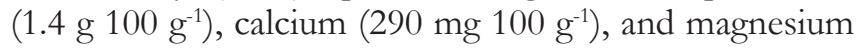

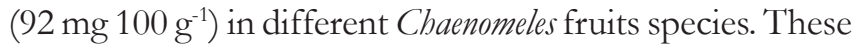
data are higher than what we found in Chaenomeles japonica.

A comparison among the inorganic ions content of Japanese quince juice and other fruits can be done considering that the content of inorganic ions of orange juice is (Hendrix and Redd, 1995): potassium (116$\left.265 \mathrm{mg} 100 \mathrm{ml}^{-1}\right)$, calcium (6-29 mg $\left.100 \mathrm{ml}^{-1}\right)$, magnesium

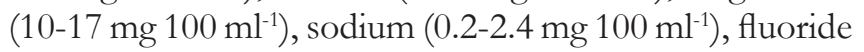
(0.1-0.2 mg $100 \mathrm{ml}^{-1}$ ) and chloride (3.6-13.2 mg $100 \mathrm{ml}^{-1}$ ). The content of inorganic ions of apple juice is (Lea, 
1995): potassium (90-150 mg $\left.100 \mathrm{ml}^{-1}\right)$, calcium (3-12 mg $100 \mathrm{ml}^{-1}$ ), and magnesium (4-7 mg $100 \mathrm{ml}^{-1}$ ). The content of potassium of Japanese quince juices was similar to that of Citrus juices (Hendrix and Redd, 1995). This result is important for the potassium intake.

\section{Statistical analyses}

Pearson's correlation coefficients calculated among the total constituents of Japanese quince genotypes fresh juice are presented in the Table 6 . The content of sugars and organic acids was slightly correlated $(0.42 *)$. The content of cations and anions was also slightly correlated $\left(-0.46^{*}\right)$.

From the point of view of the horticultural breeding and plants selection it is interesting the result that no strong correlations have appeared between the constituents of the Japanese quince juice (sugars, organic acids, amino acids and inorganic ions). This result indicates the possibility for the development of some genotypes containing high amounts of sugars, amino acids and inorganic ions and low amounts of organic acids, in order that the taste of the juice is no acid. Ros et al. (2004) reported the possibility to develop varieties of Japanese quince with high content of vitamin $\mathrm{C}$ and phenolic compounds, and low acid content.

The analysis of principal components (Fig. 4) of the genotypes of Japanese quince shows that they are separated along axis. The composition of the juices extracted from the genotypes of the Lithuanian Japanese quince is different to the composition of the juices extracted from the genotypes of the Latvian Japanese quince, since they are separated along the horizontal and vertical axis. The different location of the genotypes of the Japanese quince in the principal components analysis (Fig. 4) indicates differences between the genotypes that are useful when varieties with specific characteristics of the juice are developed. It indicates interesting possibilities for plant selection and further improvement by horticultural breeding. Since it is need to separate factors due to the environment from factors due to the genetic of the plants, is necessary to have other approach based in the use of clones of Japanese quince. This work of research is still in development.

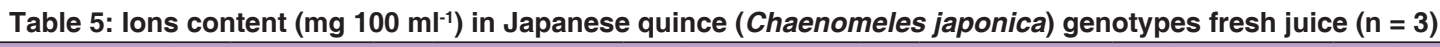

\begin{tabular}{|c|c|c|c|c|c|c|c|}
\hline Genotypes & Sodium & Ammonium & Potassium & Magnesium & Calcium & Fluoride & Chloride \\
\hline D 3-122 & $5.1^{b}$ & $1.2^{\mathrm{a}}$ & $175^{\mathrm{c}}$ & $3.9^{f}$ & $11.9^{d}$ & $96^{b}$ & $8.1^{b}$ \\
\hline D 5-96 & $3.4^{d}$ & nd & $145^{d}$ & $4.9^{d}$ & $13.2^{c}$ & nd & nd \\
\hline D $10-19$ & $4.1^{c}$ & $0.6^{c}$ & $158^{c}$ & $5.3^{d}$ & $15.1^{\mathrm{b}}$ & $82^{c}$ & $4.8^{d}$ \\
\hline NV 14-73 & $3.4^{d}$ & $0.4^{d}$ & $177^{c}$ & $7.3^{b}$ & $12.4^{d}$ & $120^{\mathrm{a}}$ & $5.2^{d}$ \\
\hline NV 15-97 & $2.6^{e}$ & $1.4^{\mathrm{a}}$ & $173^{c}$ & $8.7^{\mathrm{a}}$ & $13.0^{c}$ & $101^{b}$ & $3.7^{e}$ \\
\hline NV 17-18 & $2.7^{e}$ & $0.3^{d}$ & $146^{d}$ & $4.4^{e}$ & $9.2^{\mathrm{e}}$ & $70^{d}$ & $4.9^{d}$ \\
\hline NV 18-34 & $5.3^{b}$ & $0.9^{b}$ & $150^{d}$ & $4.4^{e}$ & $10.3^{e}$ & $74^{d}$ & $8.1^{b}$ \\
\hline NV 19-27 & $4.2^{c}$ & $1.5^{\mathrm{a}}$ & $167^{\circ}$ & $4.2^{\mathrm{e}}$ & $9.1^{\mathrm{e}}$ & $87^{c}$ & $5.1^{d}$ \\
\hline NV 19-44 & $3.4^{d}$ & $1.0^{\mathrm{ab}}$ & $165^{c}$ & $6.5^{\mathrm{c}}$ & $11.0^{d}$ & $25^{e}$ & $1.5^{\dagger}$ \\
\hline NV 19-64 & $4.3^{c}$ & $0.7^{b}$ & $163^{c}$ & $5.1^{d}$ & $8.0^{e}$ & $80^{c}$ & $5.1^{d}$ \\
\hline NV 19-108 & $1.9^{f}$ & $0.2^{\mathrm{e}}$ & $149^{d}$ & $3.8^{f}$ & $9.8^{e}$ & $122^{\mathrm{a}}$ & $9.4^{\mathrm{a}}$ \\
\hline RG 1-27 & $3.7^{d}$ & $0.4^{d}$ & $188^{b}$ & $6.6^{c}$ & $11.7^{d}$ & nd & nd \\
\hline RG 6-104 & $2.6^{e}$ & $0.6^{c}$ & $187^{b}$ & $4.2^{\mathrm{e}}$ & $10.8^{e}$ & $65^{d}$ & $6.8^{c}$ \\
\hline RG 6-111 & $3.7^{d}$ & $1.2^{\mathrm{a}}$ & $157^{c}$ & $5.4^{d}$ & $13.7^{c}$ & nd & nd \\
\hline RG 6-132 & $12.3^{a}$ & $0.8^{\mathrm{b}}$ & $187^{b}$ & $7.7^{b}$ & $18.5^{\mathrm{a}}$ & nd & nd \\
\hline$R G$ 7-50 & $3.3^{d}$ & $0.8^{\mathrm{b}}$ & $182^{b}$ & $7.4^{\mathrm{b}}$ & $11.5^{d}$ & nd & nd \\
\hline RG 7-69 & $0.4^{g}$ & $0.4^{\mathrm{d}}$ & $206^{a}$ & $4.1^{\mathrm{e}}$ & $11.8^{d}$ & nd & nd \\
\hline RG 8-22 & $3.2^{d}$ & $0.3^{e}$ & $214^{a}$ & $5.5^{d}$ & $12.7^{d}$ & $21^{\mathrm{e}}$ & $1.4^{\dagger}$ \\
\hline RG 8-25 & $5.5^{b}$ & $0.6^{c}$ & $208^{a}$ & $6.4^{c}$ & $11.3^{d}$ & nd & nd \\
\hline Range & $0.4-12.3$ & $0.2-1.5$ & $145-214$ & 3.8-8.7 & $8.0-15.1$ & 21-122 & $1.4-9.4$ \\
\hline Mean & 4.0 & 0.7 & 174 & 5.6 & 11.8 & 79 & 5.3 \\
\hline$s_{x}$ & 2.4 & 0.4 & 21 & 1.5 & 2.4 & 32 & 2.5 \\
\hline
\end{tabular}

nd: no detected. Means in column with different letters $(a-f)$ are significantly different $(p<0.05)$

Table 6: Pearson's correlation coefficients calculated among the total constituents of Japanese quince (Chaenomeles japonica) genotypes fresh juice

\begin{tabular}{|c|c|c|c|c|c|}
\hline Of Japanese quince (Chaenomeles japonica) genotypes fresh juice & & 1 & 2 & 3 & 4 \\
\hline 1 & Total sugars & & & & \\
\hline 2 & Total organic acids & $0.42^{*}$ & & & \\
\hline 3 & Total amino acids & 0.13 & -0.20 & & \\
\hline 4 & Total cations & 0.24 & 0.22 & 0.28 & \\
\hline 5 & Total anions & -0.17 & 0.29 & -0.23 & $-0.46^{*}$ \\
\hline
\end{tabular}




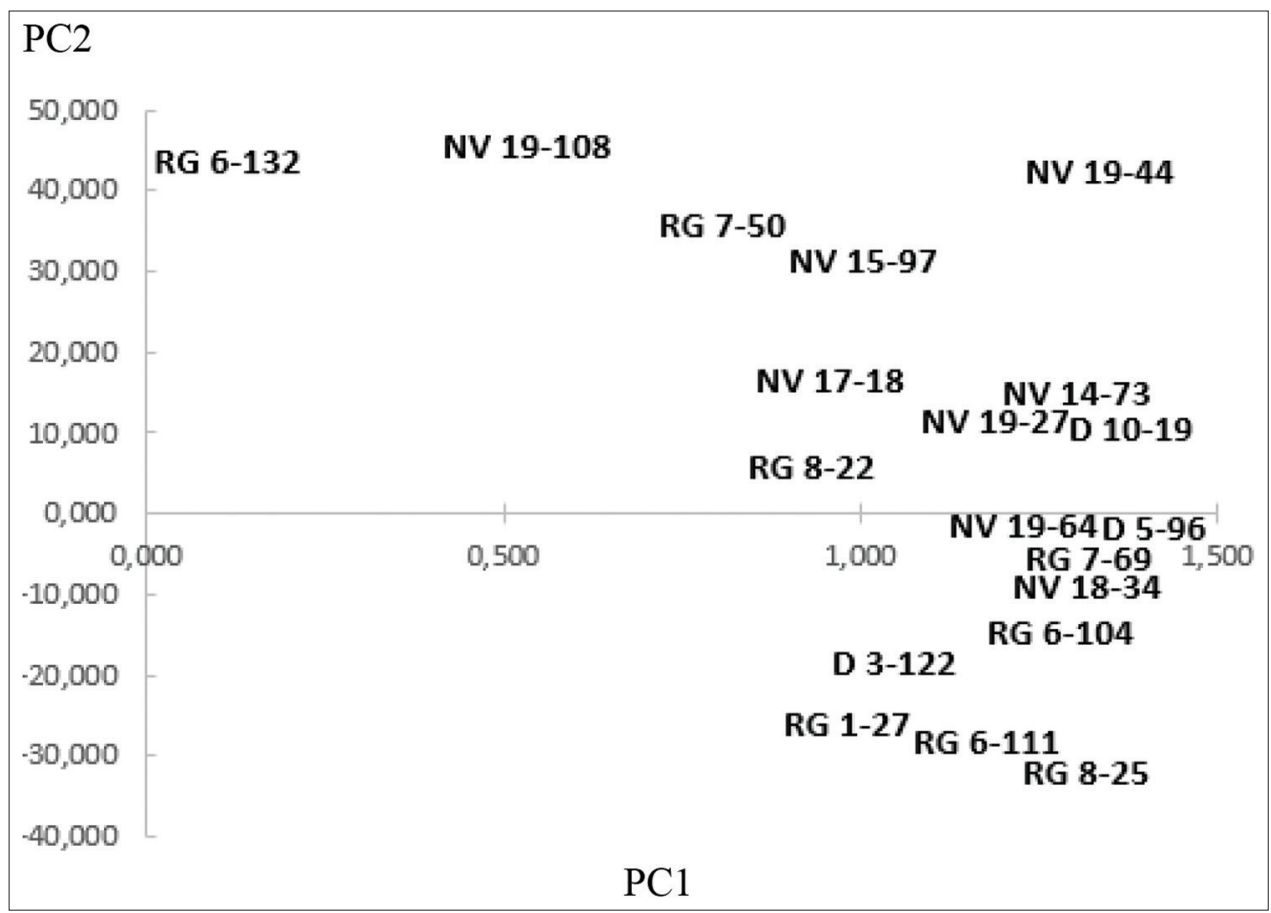

Fig. 4. Principal component analysis of the composition of Japanese quince (Chaenomeles japonica) genotypes fresh juice. For the Principal Component 1 (PC1) the Eigenvalues, Variance (\%) and Accumulated variance (\%) were 1.79, 35.9 and 35.9, respectively. For the Principal Component 2 (PC2) the Eigenvalues, Variance (\%) and Accumulated variance (\%) were 1.50, 30.0 and 65.9, respectively.

\section{CONCLUSIONS}

The different genotypes in the specie Chaenomeles japonica produce fruits rich in juice. The juice is very acidic, with a high concentration of organic acids (malic and quinic acids), a mean concentration of sugars (fructose, glucose and sorbitol), and a moderate concentration of amino acids (glutamic acid, asparagine and aspartic acid) and inorganic ions (potassium and fluoride). Due to its characteristics and composition, Chaenomeles japonica fruit juice should be useful for the food industry, especially as an acidulant with high antioxidant properties (Hellín et al., 2003; Ros et al., 2004), previous results on acidulant with high antioxidant properties of Chaenomeles japonica fruit juice. The characteristics of Chaenomeles japonica juice reported previously and also these described in this manuscript suggest that Chaenomeles japonica juice could be stabilized by High Hydrostatic Pressures (Hurtado et al., 2019a,b), with a better preservation of the thermolabile nutritional compounds. The variability in juice characteristics with statistically significative differences revealed between genotypes offer a possibility for selection and further development through plant breeding.

\section{DECLARATION OF CONFLICTING INTERESTS}

The authors declared no potential conflicts of interest with respect to the research, authorship, and/or publication of this article.

\section{FUNDING}

This research has been carried out with financial support from the Commission of the European Community, Agriculture and Fisheries (FAIR) specific RTD programme, CT97-3894, 'Japanese quince (Chaenomeles japonica) - a new European fruit crop for production of juice, flavour and fibre'. It does not necessarily reflect its views and in no way anticipates the Commissions' future policy in this area.

\section{Authors' contributions}

This manuscript contains a part of the results from the project 'Japanese quince (Chaenomeles japonica) - a new European fruit crop for production of juice, flavour and fibre'. K. Rumpunen cultivated the Chaenomeles japonica genotypes in Sweden, which were sent to Spain. M. P. Hellín and M. J. Jordán made the extraction of the Chaenomeles japonica genotypes fresh juice. M. P. Hellín and J. M. Ros made the chromatographic analysis of the juices and the statistical analysis of the data. Finally, the manuscript has been prepared by J. M. Ros, with the approval of all the authors.

\section{REFERENCES}

Ackermann, J., M. Fischer and R. Amadò. 1992. Changes in sugars, acids, and amino acids during ripening and storage of apples (cv. Glockenapfel). J. Agric. Food Chem. 40: 1131-1134.

Apolinar-Valiente, R., I. Romero-Cascales, E. Gómez-Plaza and 
J. M. Ros-García. 2017. Degradation of Monastrell grapes skin: Effect of individual enzymatic activities and their synergic combination. Eur. Food Res. Technol. 243: 1933-1942.

Baranowska-Bosiacka, I., B. Bosiacka, J. Rast, I. Gutowska, J. Wolska, E. Rębacz-Maron, K. Dębia, K. Janda, J. Korbecki and D. Chlubek. 2017. Macro-and microelement content and other properties of Chaenomeles japonica L. fruit and protective effects of its aqueous extract on hepatocyte metabolism. Biol. Trace Elem. Res. 178: 327-337.

Barco, A., S. Benetti, C. De Risi, P. Marchetti, G. P. Pollini and V. Zanirato. 1997. D-(-)-Quinic acid: A chiron store for natural product synthesis. Tetrahedron. Asymmetry. 8: 3515-3545.

Durec, J., D. Kozelová, E. Matejková, M. Fikselová and S. Jakabová. 2019. Fruit as a source of antioxidants and trends in its consumption. Slov. J. Food Sci. 13: 251-257.

Golubev, V. N., A. A. Kolechik and U. A. Rigavs. 1990. Carbohydrate complex of the fruit of Chaenomeles maulei. Chem. Nat. Comp. 26: 387-390.

González-Hidalgo, I., D. A. Moreno, C. García-Viguera and J. M. RosGarcía. 2019. The effect of industrial freezing on the physical and nutritional quality traits in broccoli. Food Sci. Technol. Int. 25: 56-65.

Górnaś, P., I. Pugajeva and D. Seglina. 2014. Seeds recovered from by-products of selected fruit processing as a rich source of tocochromanols: RP-HPLC/FLD and RP-UPLC-ESI/MS ${ }^{n}$ study. Eur. Food. Res. Technol. 239: 519-524.

Heimler, D. and A. Pieroni. 1992. Influence of environmental factors (acid rains and long term storage) on the concentration of carboxylic acids in apple fruits. Agrochimica. 36: 494-499.

Hellín, P., J. M. Ros and J. Laencina. 2001. Changes in high and low molecular weight carbohydrates during Rhizopus nigricans cultivation on lemon peel. Carbohydr. Polym. 45: 169-174.

Hellín, P., R. Vila, M. J. Jordán, J. Laencina, K. Rumpunen and J. M. Ros. 2003. Characteristics and composition of Chaenomeles fruit juice. In: K. Rumpunen (Ed.), Japanese Quince-Potential Fruit Crop for Northern Europe, Swedish University of Agricultural Sciences, Alnarp, Sweden, pp. 127-140.

Hendrix, C. M. and J. B. Redd. 1995. Chemistry and technology of Citrus juices and their by-products. In: P. R. Ashurst (ed.), Production and Packaging of Non-Carbonated Fruit Juices and Fruit Beverages, Blackie Academic and Professional, Glasgow, United Kingdom.

Huang, P. Q. 1999. D-Quinic acid, a versatile Chiron in organic synthesis. Chin. J. Org. Chem. 19: 364-373.

Hurtado, A., M. D. Guàrdia, P. Picouet, A. Jofré, S. Bañón and J. M. Ros. 2019a. Shelf-life extension of multi-vegetables smoothies by high pressure processing compared with thermal treatment. Part I: Microbial and enzyme inhibition, antioxidant status and physical stability. J. Food Process. Preserv. 43: e14139.

Hurtado, A., M. D. Guàrdia, P. Picouet, A. Jofré, S. Bañón and J. M. Ros. 2019b. Shelf-life extension of multi-vegetables smoothies by high pressure processing compared with thermal treatment. Part II: Retention of selected nutrients and sensory quality. J. Food Proc. Preserv. 43: e14210.

Kikowska, M. A., M. Chmielewska, A. Włodarczyk, E. StudzinskaSroka, J. Zuchowski, A. Stochmal, M. Kotwicka and B. Thiem. 2018. Effect of pentacyclic triterpenoids-rich callus extract of Chaenomeles japonica (Thunb.) Lindl. ex Spach on viability, morphology, and proliferation of normal human skin fibroblasts. Molecules. 23: 3009.

Kikowska, M., M. Derda, B. Thiem, A. Włodarczyk, J. Długaszewska, A. Stochmal, J. Żuchowski and E. Hada. 2019a. Evaluation of antiamoebic and antimicrobial activities in vitro of Chaenomeles japonica (Thunb.) Lindl. ex spach extracts. Acta Biol. Cracov. Ser. Bot. 61: 47-58.

Kikowska, M., A. Włodarczyk, M. Rewers, E. Sliwinska, E. Studzinska-Sroka, E. Witkowska-Banaszczak, A. Stochmal, J. Zuchowski, J. Dlugaszewska and B. Thiem. 2019b. Micropropagation of Chaenomeles japonica: A step towards production of polyphenol-rich extracts showing antioxidant and antimicrobial activities. Molecules. 24: 1314.

Komar-Tyomnaya, L. and E. Dunaevskaya. 2017. The content of essential elements in the flowers and fruits of chaenomeles (Chaenomeles Lindl.). AGROFOR Int. J. 2: 48-54.

Lea, A. G. H. 1995. Apple juice. In: P. R. Ashurst (Ed.), Production and Packaging of Non-Carbonated Fruit Juices and Fruit Beverages. Blackie Academic and Professional, Glasgow, United Kingdom.

Lesinska, E. 1987. Characteristics of sugars and acids in the fruits of East Asian quince. Die Nahrung. 31: 763-765.

Lesinska, E, R. Przybylski and N. A. M. Eskin. 1988. Some volatile and nonvolatile flavor components of the dwarf quince (Chaenomeles japonica). J. Food Sci. 53: 854-856.

Lykholat, Y. V., N. O. Khromykh, T. Y. Lykholat, O. O. Didur, O. A. Lykholat, T. V. Legostaeva, A. M. Kabar, T. V. Sklyar, V. M. Savosko, I. M. Kovalenko, V. R. Davydov, Y. V. Bielyk, K. O. Volyanik, A. V. Onopa, K. A. Dudkina and I. P. Grygoryuk. 2019. Industrial characteristics and consumer properties of Chaenomeles Lindl. fruits. Ukr. J. Ecol. 9: 132-137.

Miao, J., X. Li, C. Zhao, X. Gao, Y. Wang and W. Gao. 2018. Active compounds, antioxidant activity and glucosidase inhibitory activity of different varieties of Chaenomeles fruits. Food Chem. 248: 330-339.

Ros, J. M., J. Laencina, P. Hellín, M. J. Jordán, R. Vila and K. Rumpunen. 2004. Characterization of juice in fruits of different Chaenomeles species. LWT-Food Sci. Technol. 37: 301-307.

Rumpunen, K. 1995. Chaenomeles a novel source for pectic substances, organic acids and aromatic compounds. In: C. García-Viguera, M. Castañer, M. I. Gil, F. Ferreres and F. A. Tomás-Barberán (Eds.), Current Trends in Fruit and Vegetables Phytochemistry. Consejo Superior de Investigaciones Científicas, Madrid, Spain, pp. 271-276.

Rumpunen, K., D. Kviklys, E. Kaufmane and L. Garkava. 1998. Breeding Chaenomeles a new aromatic fruit crop. Acta Hortic. 484: 211-216.

Rumpunen, K. 2002. Chaenomeles: Potential New Fruit Crop for Northern Europe. In: J. Janick and A. Whipkey (Eds.), Trends in New Crops and New Uses. American Society Horticultural Science Press, Alexandria, Virginia, USA, pp. 385-392.

Saura, D., J. A. Cánovas, J. M. Ros, J. M. Núñez and J. Laencina. 1990. Lemon juice applications as natural acidulant in foods. Proc. Int. Congr. Food Technol. Dev. 3: 911-919.

Tarko, T., A. Duda-Chodak, P. Satora, P. Sroka, P. Pogoń and J. Machalica. 2014. Chaenomeles japonica, Cornus mas, Morus nigra fruits characteristics and their processing potential. J. Food Sci. Technol. 51: 3934-3941.

Thomas, M., M. J. C. Crépeau, K. Rumpunen and J. F. Thibault. 2000. Dietary fibre and cell-wall polysaccharides in the fruits of Japanese quince (Chaenomeles japonica). LWT Food Sci. Technol. 33: 124-131.

Thomas, M. and J. F. Thibault. 2002. Cell-wall polysaccharides in the fruits of Japanese quince (Chaenomeles japonica): Extraction and preliminary characterisation. Carbohydr. Polym. 49: 345-355

Thomas, M., F. Guillemin, F. Guillon and J. F. Thibault. 2003. Pectins in the fruits of Japanese quince (Chaenomeles japonica). Carbohydr. Polym. 53: 361-372. 
Valcheva-Kuzmanova, S. V., P. N. Denev and M. H. Ognyanov. 2018. Chemical composition and antioxidant activity of Chaenomeles maulei fruit juice. J. Biomed. Clin. Res. 11: 41-48.

van Gorsel, H., C. Li, E. L. Kerbel, M. Smits and A. A. Kader. 1992. Compositional characterization of Prune juice. J. Agric. Food Chem. 40: 784-789.

Viljakainen, S. K. and S. V. Laakso. 2002. Acidity reduction in Northern region berry juices by the malolactic bacterium Oenococcus oeni. Eur. Food Res. Technol. 214: 412-417.
Viljakainen, S., A. Visti and S. Laakso. 2002. Concentrations of organic acids and soluble sugars in juices from Nordic berries. Acta Agric. Scand. B Soil Plant Sci. 52: 101-109.

Watychowicz, K., K. Janda, K. Jakubczyk and J. Wolska. 2017. Chaenomeles health promoting benefits. Rocz. Państw. Zakł. Hig. 68: 217-227.

Wojdyło, A., J. Oszmiański and I. Bober. 2008. The effect of addition of chokeberry, flowering quince fruits and rhubarb juice to strawberry jams on their polyphenol content, antioxidant activity and colour. Eur. Food Res. Technol. 227: 1043-1051. 